\title{
Age-dependent myocardial transcriptomic changes in the rat. Novel insights into atrial and ventricular arrhythmias pathogenesis
}

\section{Modificări transcriptomice dependente de vârstă în miocardul de șobolan. Noi aspecte referitoare la patogeneza aritmiilor atriale și ventriculare}

\author{
Alina Scridon ${ }^{1,2}$, Emmanuelle Fouilloux-Meugnier ${ }^{3}$, Emmanuelle Loizon $^{3}$, \\ Marcel Perian ${ }^{1}$, Sophie Rome ${ }^{3}$, Claude Julien², Christian Barrès ${ }^{2}$, Philippe \\ Chevalier ${ }^{2,4}$ \\ 1.Physiology Department, University of Medicine and Pharmacy of Tîrgu Mureș, 540139, \\ Tîrgu Mureș, Romania \\ 2. Unité de Neurocardiologie, EA4612, Université Lyon 1, F-69008, Lyon, France \\ 3. Unité 1060 INSERM CarMen, Université Lyon 1, F-69008, Lyon, France \\ 4. Hospices Civils de Lyon, Hôpital Louis Pradel, Service de Rythmologie, 69500, Bron, France
}

\begin{abstract}
Background: Aging is associated with significantly increased prevalence of cardiac arrhythmias, but transcriptional events that underlie this process remain to be established. To gain deeper insight into molecular mechanisms of aging-related cardiac arrhythmias, we performed $m R N A$ expression analysis comparing atrial and ventricular myocardium from Wistar-Kyoto (WKY) rats of different ages. Methods: Atrial and ventricular sampling was performed in 3 groups ( $n=4$ each) of young (14-week-old), adult (25-week-old), and aging (47-week-old) WKY rats. $m R N A$ expressions of 89 genes involved in cardiac arrhythmogenicity were investigated using TaqMan Low Density Array analysis. Results: Of the 89 studied genes, 40 and 64 genes presented steady atrial and ventricular expressions, respectively. All genes differentially expressed within the atria of WKY rats were up-regulated with advancing age, mainly the genes encoding for various $\mathrm{K}^{+}, \mathrm{Ca}^{2+}, \mathrm{Na}^{+}$channels, and type 6 collagen. Atrial expression levels of 19 genes were positively correlated with age. Ventricular transcriptomic analysis revealed a balance between up-regulated and down-regulated genes encoding for the same ion channels. Conclusion: Our results indicate the induction of an up-regulation transcriptional response in atrial but not ventricular myocytes with advancing age, suggesting that the two chambers undergo different molecular remodeling programs. Aging atria displayed a transcriptomic profile consistent with higher propensity to arrhythmias, including up-regulation of genes encoding for $I_{\rho} I_{C a-L^{\prime}}, I_{C a-P}, I_{N a}$ outward $K^{+}$currents, and collagen, while ventricular transcriptome did not
\end{abstract}

*Corresponding author: Alina Scridon, Physiology Department, University of Medicine and Pharmacy of Tîrgu Mureș, Romania, phone: 0040 (0)2 65215551 (175), e-mail: alina.scridon@umftgm.ro 
seem to be significantly altered by aging. These observations could explain the higher propensity to atrial than ventricular arrhythmias in the elderly.

Keywords: experimental model; aging; transcriptome; atrial fibrillation; ventricular arrhythmias

\section{Rezumat}

Introducere: Deși înaintarea în vârstă este asociată cu creșterea prevalenței aritmiilor cardiace, evenimentele transcriptomice care stau la baza acestui proces rămân neelucidate. Pentru a identifica aceste mecanisme am realizat analiza expresiei ARNm la nivelul miocardului atrial și ventricular la șobolani Wistar-Kyoto (WKY) de diferite vârste. Metodă: Expresiile ARNm a 89 de gene au fost analizate prin TLDA utilizând eșantioane atriale și ventriculare de la 3 grupuri ( $n=4$ fiecare) de șobolani WKY tineri, adulți și vârstnici. Rezultate: Din cele 89 de gene, 40 și respectiv 64 de gene au prezentat expresii stabile la nivel atrial și respectiv ventricular. Toate genele exprimate diferit în atriile șobolanilor WKY au prezentat o up-regulare cu înaintarea în vârstă, în special genele care codifică canale de $\mathrm{K}^{+}, \mathrm{Ca}^{2+}, \mathrm{Na}^{+}$și colagenul de tip 6. Expresia atrială a 19 gene a fost corelată pozitiv cu vârsta. Analiza transcriptomică ventriculară a evidențiat un echilibru între genele up-regulate și down-regulate codificând aceleași canale ionice. Concluzii: Rezultatele noastre indică un răspuns transcripțional atrial, dar nu şi ventricular, caracterizat prin up-regulare odată cu inaintarea în vârstă. Aceste rezultate sugerează că cele două cavități sunt supuse unor programe de remodelare moleculară diferite. Atriile îmbătrânite au prezentat un profil transcriptomic sugestiv pentru o predispoziție crescută pentru aritmii, precum up-regularea genelor care codifică $I_{\rho} I_{C a-L}, I_{C a-p-p} I_{N a}, I_{K}$ si colagenul, în timp ce transcriptomul ventricular nu pare să fie sever alterat de înaintarea în vârstă. Aceste observații ar putea explica predispoziția mai mare pentru aritmii atriale decât ventriculare la vârstnici.

Cuvinte cheie: model experimental; înaintare în vârstă; transcriptom; fibrilație atrială; aritmii ventriculare

Received: $5^{\text {th }}$ December 2013; Accepted: 17 $7^{\text {th }}$ January 2014; Published: $14^{\text {th }}$ February 2014.

\section{Introduction}

Aging is associated with significantly increased prevalence of both atrial and ventricular arrhythmias $(1,2)$, likely due to age-associated changes in heart structure and function (3). Factors such as DNA and/or protein damage due to increased oxidative stress or late-acting mutations could account for the adverse effects of aging on myocyte structure and function (4-8). However, molecular bases underlying the increased propensity to arrhythmogenesis in the elderly remain incompletely understood. Cardiac arrhythmias have been associated with altered expression of genes encoding for proteins involved in $\mathrm{Ca}^{2+}$-handling, ion channels, extracellular matrix, or cell-cell coupling (9), but expression profiles of these genes have never been studied in relation with aging.
Transcriptome analyses seem well suited for the identification of cardiac molecular abnormalities related to aging, and may provide a starting point for our understanding of pathophysiological mechanisms linking aging to cardiac arrhythmias. However, studies on aging are rather difficult in humans due to increased incidence of cardiovascular diseases that limit survival and complicate genetic studies, making it difficult to determine to what extent mRNA abnormalities are due to aging and not to other sources of biological variability (10). On the other hand, Wistar-Kyoto (WKY) rats are free from cardiovascular diseases (11-13); this makes WKY rats a good surrogate for human aging, allowing identification of age-associated changes in gene expression without interference from concomitant disorders. 
In order to gain deeper insights into the molecular pathophysiology of aging-related cardiac arrhythmogenesis and to identify potential molecular markers and targets for novel antiarrhythmic therapies, we performed mRNA expression analysis using TaqMan Low Density Array (TLDA) analysis, comparing atrial and ventricular myocardium from WKY rats of different ages. Three stages of the aging process, 14 weeks of age, 25 weeks of age, and 47 weeks of age, corresponding to young, adult, and aging animals, respectively, were chosen in order to investigate and compare the transcriptome during aging in WKY rats.

\section{Material and methods}

\section{Animals}

Three groups of male WKY rats 14 weeks (further mentioned as young; $n=4$ ), 25 weeks (further mentioned as adult; $n=4$ ), and 47 weeks (further mentioned as aging; $n=4$ ) of age were purchased from Elevage Janvier (Le Genest Saint Isle, France).

All animals were housed in groups of two to three rats per cage in a climate-controlled room $\left(21^{\circ}\right.$ to $\left.24^{\circ} \mathrm{C}\right)$, with a $12-\mathrm{h} / 12-\mathrm{h}$ light/dark cycle, in an accredited animal facility, and had free access to standard rat pellets and tap water.

All experiments were performed in compliance with the French Ministry of Agriculture guidelines for animal experimentation and were approved by the local Animal Ethics Committee.

\section{Heart sampling}

All animals were euthanized with an intraperitoneal injection of a terminal dose of sodium pentobarbital ( $>100 \mathrm{mg} / \mathrm{kg}$ ). The hearts were excised and weighted; the left atrium and ventricle were isolated, placed in sterile dry tubes, snap frozen in liquid nitrogen, and stored at $-80^{\circ} \mathrm{C}$ until processing.

\section{Gene expression analysis}

RNA extraction. Total RNA was isolated from frozen biopsies using TRIzol ${ }^{\circledR}$ Reagent (Life Technologies; Villebon sur Yvette, France) following manufacturer's instructions. RNA concentration was measured using Nanodrop ND1000 (Thermo Scientific; Illkirch, France) and quality was verified using the Agilent 2100 BioAnalyser (Agilent Technologies; Massy, France).

TaqMan Low Density Array analysis. To identify altered gene expression, we used a TLDA to examine the expression of 89 genes encoding for ion channels, proteins of the extracellular matrix, and proteins involved in cell-cell coupling. The choice of the 89 genes selected for mRNA expression analysis was based on their conclusive role in cardiac arrhythmogenicity (9). A detailed list of the 89 examined genes is provided in Table I. For the present study, the TLDA card was configured into four identical 89 genes set. For each set of genes, we used 6 endogenous control genes: Ppia, $\beta$-actin, Gapdh, Hprt1, Tbp, and 18 s RNA.

Briefly, one $\mu \mathrm{g}$ of total RNA was reverse-transcribed to complementary DNA (cDNA) by using High-Capacity cDNA Reverse Transcription Kits (Applied Biosystems) following manufacturer's instructions. The cDNA (2 $\mu \mathrm{L})$ was mixed with $48 \mu \mathrm{L}$ of $\mathrm{H}_{2} \mathrm{O}$ and $50 \mu \mathrm{L}$ of 2X TaqMan Universal PCR Mix (Applied Biosystems). Each sample (100 $\mu \mathrm{L})$ was loaded into a port of the micro-fluid card and run on an ABI 7900HT System (Applied Biosystems) for 2 min at $50^{\circ} \mathrm{C}, 10 \mathrm{~min}$ at $94.5^{\circ} \mathrm{C}$, followed by 40 cycles of $30 \mathrm{~s}$ at $97^{\circ} \mathrm{C}$ and $1 \mathrm{~min}$ at $59.7^{\circ} \mathrm{C}$.

The TLDA data were analyzed using SDS 2.3 software (Applied Biosystems). Threshold cycle data for all target and control genes were transformed into molecule numbers (attomoles) considering polymerase chain reaction efficiency of $100 \%$. Gene expression levels were normalized using TBP. 
Table I. List of the 89 genes for which mRNA expressions were studied in left atrial and ventricular samples of WKY rats of different ages.

\begin{tabular}{|c|c|}
\hline Symbol & Name \\
\hline Cacnalc & calcium channel, voltage-dependent, L type, alpha $1 \mathrm{C}$ subunit \\
\hline Cacnald & calcium channel, voltage-dependent, L type, alpha $1 \mathrm{D}$ subunit \\
\hline Cacnalg & calcium channel, voltage-dependent, T type, alpha $1 \mathrm{G}$ subunit \\
\hline Cacnalh & calcium channel, voltage-dependent, $\mathrm{T}$ type, alpha $1 \mathrm{H}$ subunit \\
\hline Cacna2d1 & calcium channel, voltage-dependent, alpha 2/delta subunit 1 \\
\hline Cacna2d2 & calcium channel, voltage-dependent, alpha 2/delta subunit 2 \\
\hline Cacnb1 & calcium channel, voltage-dependent, beta 1 subunit \\
\hline Cacnb2 & calcium channel, voltage-dependent, beta 2 subunit \\
\hline Cacnb3 & calcium channel, voltage-dependent, beta 3 subunit \\
\hline Cacnb4 & calcium channel, voltage-dependent, beta 4 subunit \\
\hline Cacng4 & calcium channel, voltage-dependent, gamma subunit 4 \\
\hline Cacng6 & calcium channel, voltage-dependent, gamma subunit 6 \\
\hline Casq1 & calsequestrin 1 (fast-twitch, skeletal muscle) \\
\hline Casq2 & calsequestrin 2 (cardiac muscle) \\
\hline Clcn2 & chloride channel 2 \\
\hline Clcn3 & chloride channel 3 \\
\hline Col6al & collagen, type VI, alpha 1 \\
\hline$D s c 2$ & desmocollin 2 \\
\hline Dsp & desmoplakin \\
\hline Gjal & gap junction protein, alpha 1 \\
\hline Gja5 & gap junction protein, alpha 5 \\
\hline Gja7 & gap junction membrane channel protein alpha 7 \\
\hline Hcnl & hyperpolarization-activated cyclic nucleotide-gated potassium channel 1 \\
\hline Hcn 2 & hyperpolarization activated cyclic nucleotide-gated potassium channel 2 \\
\hline Hcn3 & hyperpolarization-activated cyclic nucleotide-gated potassium channel 3 \\
\hline Hcn4 & hyperpolarization activated cyclic nucleotide-gated potassium channel 4 \\
\hline Kcnal & potassium voltage-gated channel, shaker-related subfamily, member 1 \\
\hline Kcna2 & potassium voltage-gated channel, shaker-related subfamily, member 2 \\
\hline Kcna3 & potassium voltage-gated channel, shaker-related subfamily, member 3 \\
\hline Kcna4 & potassium voltage-gated channel, shaker-related subfamily, member 4 \\
\hline Kcna5 & potassium voltage-gated channel, shaker-related subfamily, member 5 \\
\hline Kcna6 & potassium voltage gated channel, shaker related subfamily, member 6 \\
\hline Kcnabl & potassium voltage-gated channel, shaker-related subfamily, beta member 1 \\
\hline Kcnab2 & potassium voltage-gated channel, shaker-related subfamily, beta member 2 \\
\hline Kcnab3 & potassium voltage-gated channel, shaker-related subfamily, beta member 3 \\
\hline Kcnbl & potassium voltage gated channel, Shab-related subfamily, member 1 \\
\hline Kcnc3 & potassium voltage gated channel, Shaw-related subfamily, member 3 \\
\hline Kcnc4 & potassium voltage gated channel, Shaw-related subfamily, member 4 \\
\hline Kcndl & potassium voltage-gated channel, Shal-related subfamily, member 1 \\
\hline Kcnd2 & potassium voltage-gated channel, Shal-related subfamily, member 2 \\
\hline Kcnd3 & potassium voltage-gated channel, Shal-related subfamily, member 3 \\
\hline Kcne1 & potassium voltage-gated channel, Isk-related family, member 1 \\
\hline Kcne1l & KCNE1-like \\
\hline Kcne2 & potassium voltage-gated channel, Isk-related family, member 2 \\
\hline
\end{tabular}


Table I. (continued)

\begin{tabular}{|c|c|}
\hline Symbol & Name \\
\hline Kcne3 & potassium voltage-gated channel, Isk-related family, member 3 \\
\hline Kcne4 & potassium voltage-gated channel, Isk-related family, member 4 \\
\hline Kcnh2 & potassium voltage-gated channel, subfamily $\mathrm{H}$ (eag-related), member 2 \\
\hline Kcnh7 & potassium voltage-gated channel, subfamily H (eag-related), member 7 \\
\hline Kcnip2 & Kv channel-interacting protein 2 \\
\hline Kcnj11 & potassium inwardly rectifying channel, subfamily J, member 11 \\
\hline Kcnj12 & potassium inwardly-rectifying channel, subfamily J, member 12 \\
\hline Kcnj2 & potassium inwardly-rectifying channel, subfamily J, member 2 \\
\hline Kcnj3 & potassium inwardly-rectifying channel, subfamily $\mathrm{J}$, member 3 \\
\hline Kcnj4 & potassium inwardly-rectifying channel, subfamily J, member 4 \\
\hline Kcnj5 & potassium inwardly-rectifying channel, subfamily $\mathrm{J}$, member 5 \\
\hline Kcnj8 & potassium inwardly-rectifying channel, subfamily J, member 8 \\
\hline Kcnk1 & potassium channel, subfamily $\mathrm{K}$, member 1 \\
\hline Kcnk3 & potassium channel, subfamily $\mathrm{K}$, member 3 \\
\hline Kcnk5 & potassium channel, subfamily $\mathrm{K}$, member 5 \\
\hline Kcnn2 & potassium intermediate/small conductance calcium-activated channel, subfamily $\mathrm{N}$, member 2 \\
\hline Kcnq1 & potassium voltage-gated channel, KQT-like subfamily, member 1 \\
\hline Npr3 & natriuretic peptide receptor C/guanylate cyclase $\mathrm{C}$ (atrionatriuretic peptide receptor $\mathrm{C}$ ) \\
\hline Pakl & p21 protein $(\mathrm{Cdc} 42 / \mathrm{Rac})$-activated kinase 1 \\
\hline Myh7 & myosin, heavy chain 7 , cardiac muscle, beta \\
\hline Pkp2 & plakophilin 2 \\
\hline Ryr2 & ryanodine receptor 2 , cardiac \\
\hline Scnla & sodium channel, voltage-gated, type I, alpha \\
\hline Scn1b & sodium channel, voltage-gated, type I, beta \\
\hline Scn $2 b$ & sodium channel, voltage-gated, type II, beta \\
\hline Scn3a & sodium channel, voltage-gated, type III, alpha \\
\hline Scn3b & sodium channel, voltage-gated, type III, beta \\
\hline Scn $4 a$ & sodium channel, voltage-gated, type IV, alpha subunit \\
\hline Scn5a & sodium channel, voltage-gated, type V, alpha subunit \\
\hline Scn $7 a$ & sodium channel, voltage-gated, type VII, alpha \\
\hline $\operatorname{Scn} 9 a$ & sodium channel, voltage-gated, type IX, alpha \\
\hline Smad6 & SMAD family member 6 \\
\hline $\operatorname{Smad} 9$ & SMAD family member 9 \\
\hline Smyd2 & SET and MYND domain containing 2 \\
\hline $\operatorname{Trpc1}$ & transient receptor potential cation channel, subfamily $\mathrm{C}$, member 1 \\
\hline $\operatorname{Trpc} 3$ & transient receptor potential cation channel, subfamily C, member 3 \\
\hline $\operatorname{Trpc} 4$ & transient receptor potential cation channel, subfamily C, member 4 \\
\hline Trpc5 & transient receptor potential cation channel, subfamily C, member 5 \\
\hline Trpc6 & transient receptor potential cation channel, subfamily C, member 6 \\
\hline Trpm4 & transient receptor potential cation channel, subfamily M, member 4 \\
\hline Trpm5 & transient receptor potential cation channel, subfamily M, member 5 \\
\hline Trpv1 & transient receptor potential cation channel, subfamily V, member 1 \\
\hline $\operatorname{Trpv6}$ & transient receptor potential cation channel, subfamily V, member 6 \\
\hline $\operatorname{Tg} f b 1$ & transforming growth factor, beta 1 \\
\hline Camk2d & calcium/calmodulin-dependent protein kinase II delta \\
\hline
\end{tabular}




\section{Statistics}

Data are expressed as means \pm SE. Nonparametric ANOVA (Kruskal-Wallis test) was used for multiple comparisons. Between-group comparisons were performed using the Mann-Whitney $U$ test. Correlations were ascertained with Spearman's rank correlation method. A $P$ value of less than 0.05 was considered statistically significant. Statistical analyses were undertaken using GraphPad Prism ${ }^{\circledR}$ software (GraphPad Software; San Diego, CA).

\section{Results}

\section{Cardiac morphometry}

Compared to young and adult WKY rats, aging rats had markedly increased body weights (Table II), but there was no significant difference in heart weights between WKY rats of different ages (all $P>0.05$ ). Consequently, heart weightto-body weight ratios were significantly lower in aging WKY rats compared to young WKY rats $(P=0.04)$, while there was no significant difference between adult and young WKY rats, nor between aging and adult WKY rats (both $P>0.05$ ). Among WKY rats, body weights were significantly positively correlated with age (Spearman $r=0.96, P<0.001)$, but there was no significant correlation between heart weights and age $(P=$ 0.80 ), whilst heart weight-to-body weight ratios were significantly negatively correlated with age (Spearman $r=-0.82, P=0.01$ ).

\section{Gene expression profile}

Left atrial and ventricular gene expression levels were compared between WKY rats of different ages. Significantly altered transcripts were selected by applying a fold change-cutoff of 1.5 and a $P$-value cutoff of 0.05 .

\section{Genes with steady expression profiles}

Forty genes out of the 89 studied genes presented similar expression levels in atrial tissue samples from young, adult, and aging WKY rats (all $P>0.05$ ). These genes included genes encoding for various subunits of the L-type $\mathrm{Ca}^{2+}$ current $\left(\mathrm{I}_{\mathrm{Ca-}}\right)$, for the $\mathrm{Ca}^{2+}$-binding protein calsequestrin 1, for various subunits of the delayed rectifier $\mathrm{K}^{+}$current $\left(\mathrm{I}_{\mathrm{K}}\right)$, of the transient outward $\mathrm{K}^{+}$current $\left(\mathrm{I}_{\mathrm{to}}\right)$, of the inward rectifier $\mathrm{K}^{+}$current $\left(\mathrm{I}_{\mathrm{K} 1}\right)$, of the ATP-sensitive $\mathrm{K}^{+}$current $\left(\mathrm{I}_{\mathrm{K} \text {-ATP }}\right)$, and of the acetylcholine-activated $\mathrm{K}^{+}$current $\left(\mathrm{I}_{\mathrm{K} \text {-Ach }}\right.$ ), for various subunits of the voltage-dependent $\mathrm{Na}^{+}$current $\left(\mathrm{I}_{\mathrm{Na}}\right)$, for non-selective cation currents, connexins, for the serine/threonine-specific protein kinase, for myosin heavy chain 7 , for the N-lysine methyltransferase, and for the transforming growth factor beta (TGF $\beta$ ).

In ventricular tissue samples, 64 genes out of the 89 studied genes presented similar expression levels in young, adult, and aging WKY rats (all $P>0.05$ ). These genes included genes encoding for $\mathrm{I}_{\mathrm{Ca}-\mathrm{L}}, \mathrm{I}_{\mathrm{Na}}$, various subunits of $\mathrm{I}_{\mathrm{K}}, \mathrm{I}_{\text {to }}$, and $\mathrm{I}_{\mathrm{K} 1}$, for the hyperpolarization-activated inward current $\left(\mathrm{I}_{\mathrm{f}}\right)$, various $\mathrm{Cl}^{-}$currents, non-selective cation currents, for the atrionatriuretic pep-

Table II. Morphometric characteristics of WKY rats.

\begin{tabular}{lccc}
\hline & $\begin{array}{c}\text { Young WKY rats } \\
(\mathrm{n}=4)\end{array}$ & $\begin{array}{c}\text { Adult WKY rats } \\
(\mathrm{n}=4)\end{array}$ & $\begin{array}{c}\text { Aging WKY rats } \\
(\mathrm{n}=4)\end{array}$ \\
\hline Body weight $\mathbf{( g )}$ & $398.2 \pm 1.3$ & $509.7 \pm 4.8^{\dagger}$ & $580.0 \pm 11.7^{* \ddagger}$ \\
\hline Heart weight $(\mathbf{m g})$ & $1450.5 \pm 131.6$ & $1547.2 \pm 32.5$ & $1554.7 \pm 69.8$ \\
\hline Heart weight / body weight $\left(\mathbf{1 0}^{-3}\right)$ & $3.6 \pm 0.3$ & $3.03 \pm 0.1$ & $2.7 \pm 0.1^{*}$ \\
\hline
\end{tabular}

Data are expressed as means \pm SE. ${ }^{*} P \leq 0.04$ for aging versus young WKY rats; ${ }^{\star} P=0.02$ for aging versus adult WKY rats; ${ }^{\dagger} P=0.02$ for adult versus young WKY rats. $P$ values refer to comparisons between groups based on the Mann-Whitney $U$ test. 
tide receptor $\mathrm{C}$, for the serine/threonine-specific protein kinase, for various proteins involved in TGF $\beta$ signaling, as well as for the N-lysine methyltransferase. None of the studied genes encoding for $\mathrm{I}_{\mathrm{K} 1}, \mathrm{I}_{\mathrm{K} \text {-ATP, }} \mathrm{I}_{\mathrm{K}-\mathrm{Ach}}, \mathrm{Ca}^{2+}$-binding proteins, or proteins involved in intercellular connectivity (connexins 40, 45, and 43, desmocollin 2, and desmoplakin) presented significantly different expression levels between the three groups.

Twenty-eight of the studied genes presented steady profiles in both atrial and ventricular tissue samples. These genes included most of the genes encoding for $\mathrm{I}_{\mathrm{Na}}$, for various outward $\mathrm{K}^{+}$currents, $\mathrm{Ca}^{2+}$-currents, for the $\mathrm{Ca}^{2+}$-binding protein calsequestrin 1 , for connexin- 45 , for the serine/threonine-specific protein kinase, and for the N-lysine methyltransferase.

\section{Age-specific transcripts}

Differentially expressed genes between young and adult WKY rats. Sixteen genes were differentially expressed with at least a 1.5 -fold change in atrial tissue samples from young WKY rats compared to adult WKY rats. All these 16 genes were significantly up-regulated in adult compared to young rats. The most significant up-regulation was observed in Hcn2, encoding for $\mathrm{I}_{\mathrm{f}}$, which was 3.8 times more expressed in the atria of adult compared to young rats. Genes encoding for proteins involved in $\mathrm{Ca}^{2+}$-handling (Cacnb1, Kcnn2, and Ryr2), for $\mathrm{I}_{\text {to }}$ (Kcna4), and for a protein involved in TGF $\beta$ signaling (Smad6) were also significantly up-regulated in adult compared to young WKY rats.

In ventricular tissue samples, 4 genes were differentially expressed between young and adult WKY rats, 3 of which were up-regulated, while 1 was down-regulated in adult compared to young WKY rats. The most significant up-regulation was observed in Myh7, encoding for myosin heavy chain 7, which was 3 times more expressed in adult than in young WKY rats. Cacng4 and $S m a d 9$, encoding for the gamma subunit 4 of the voltage-gated $\mathrm{Ca}^{2+}$-current and for a protein involved in TGF $\beta$ signaling, respectively, presented both 1.5-fold higher expressions in adult compared to young WKY rats. Contrarily, Col6a1, encoding for non-fibrillar type VI collagen, was 1.5-fold less expressed in adult compared to young WKY rats. None of the genes with significantly different expressions within the atrial tissue presented a similar change within the ventricular tissue.

Differentially expressed genes between adult and aging WKY rats. Thirteen genes were differentially expressed in atrial tissue samples from adult compared to aging WKY rats. All 13 genes were significantly up-regulated in aging compared to adult WKY rats. The most significant up-regulation was observed in Kcnbl and Kcna5, both encoding for the ultrarapid component of $\mathrm{I}_{\mathrm{K}}\left(\mathrm{I}_{\mathrm{Kur}}\right)$, which were 6-times and 4-times, respectively, more expressed in the atria of aging compared to adult WKY rats. Col6a1, encoding for type VI collagen, and Npr3, encoding for the atrionatriuretic peptide receptor $\mathrm{C}$, were also significantly up-regulated in aging compared to adult WKY rats.

In ventricular tissue samples, 8 genes were differentially expressed between adult and aging WKY rats, 4 of which were significantly up-regulated, while 4 were significantly down-regulated in aging compared to adult WKY rats. The most significant up-regulation was observed in Kcnal, encoding for $\mathrm{I}_{\mathrm{K}}$, which presented a 15fold higher expression level in aging compared to adult WKY rats, while the most significant down-regulation was observed in Kcna4, encoding for $I_{t}$, which was 11-times less expressed in aging WKY rats than in adult WKY rats. The other up-regulated genes were Kcna6, encoding for $I_{K}$, which had a 10-fold higher expression in aging than in adult WKY rats, Kcna3, encoding for $\mathrm{I}_{\text {to }}$, which had a 5-fold higher expression in aging than in adult WKY rats, and Scn $2 b$, encoding for a beta subunit of $\mathrm{I}_{\mathrm{Na}}$, which was 3-times 
more expressed in aging than in adult WKY rats. The other down-regulated genes were Kcna2, encoding for $\mathrm{I}_{\mathrm{Kur}}$, which had a 7-fold lower expression in aging than in adult WKY rats, $M y h 7$, encoding for myosin heavy chain 7, which had a 3-fold lower expression in aging than in adult WKY rats, and Scn4a, encoding for $\mathrm{I}_{\mathrm{Na}}$, which was 1.7-times less expressed in aging than in adult WKY rats. Again, none of the genes with significantly different expression levels within the atrial tissue presented a similar change within the ventricular tissue.

Differentially expressed genes between young and aging WKY rats. Fourteen genes were differentially expressed in atrial tissue samples from young compared to aging WKY rats. All 14 genes were significantly up-regulated in aging compared to young rats. The most significant up-regulation was observed in $\mathrm{Npr} 3$, encoding for the atrionatriuretic peptide receptor $\mathrm{C}$, which was 7-times more expressed in the atria of aging compared to young WKY rats. Hcn4, encoding for $\mathrm{I}_{\mathrm{f}}$, Kcna5, Kcnj11, Kcnq1, encoding for various outward $\mathrm{K}^{+}$currents, and Col6al, encoding for type VI collagen, were also significantly up-regulated in aging compared to young WKY rats.

In ventricular tissue samples, 7 genes were differentially expressed between young and aging WKY rats, 4 of which were significantly up-regulated and 3 were significantly down-regulated in aging compared to young WKY rats. The most significant up-regulation was observed in Kcnab2 and Kcnal, both encoding for $\mathrm{I}_{\mathrm{K}}$, which were 22-times and 21-times, respectively, more expressed in aging than in young WKY rats, while the most significant down-regulation was observed in Kcna4, encoding for $\mathrm{I}_{\text {to }}$, which was 13-times less expressed in aging than in young WKY rats. The other up-regulated genes were Kcna6, encoding for $\mathrm{I}_{\mathrm{K}}$, which had a 14fold higher expression in aging than in young WKY rats, and Kcna3, encoding for $\mathrm{I}_{\text {to }}$, which had a 3.5-fold higher expression in aging than in young WKY rats. The other down-regulated genes were Kcna2, encoding for $\mathrm{I}_{\text {Kur }}$, which had a 5-fold lower expression in aging than in young, and Kcnabl, encoding for $\mathrm{I}_{\mathrm{K}}$, which was 2.4-times less expressed in aging than in young WKY rats. Again, none of the genes with significantly different expressions within the atrial tissue presented a similar change within the ventricular tissue.

\section{Gene expression levels and advancing age}

Atrial transcriptomic analysis revealed 22 genes significantly differentially expressed between all three groups. One of these 22 genes presented a peak at adult age (Hcn2), two presented their lowest expression levels at adult age (Kcna3 and Kcnbl), while the remaining presented a continuous increase with advancing age (Figure 1). For these 19 remaining genes, atrial expression levels were significantly positively correlated with age. These 19 genes included genes encoding for proteins involved in $\mathrm{Ca}^{2+}$-handling, $\mathrm{Cl}^{-}$currents, outward $\mathrm{K}^{+}$and non-selective cationic currents, voltage-gated $\mathrm{Na}^{+}$currents, the pacemaker current, collagen, proteins involved in intercellular connectivity, and atrionatriuretic peptide receptors.

At the ventricular level, 10 genes were significantly differentially expressed between all three groups. Four of these genes (Cacnb2, Cacng4, Kcna2, and Myh7) presented a peak at adult age, two (Col6al and Kcna3) presented their lowest expression levels at adult age, while two (Kcnal and Kcna6) presented a continuous increase, and two (Kcna4 and Kcnabl) presented a continuous decrease with advancing age (Figure 2). For 2 genes (Kcnal and Kcna6), ventricular expression levels were strongly positively correlated with age, whilst for other 2 genes (Kcna4 and Kcnabl) ventricular expression levels were strongly negatively correlated with age. 


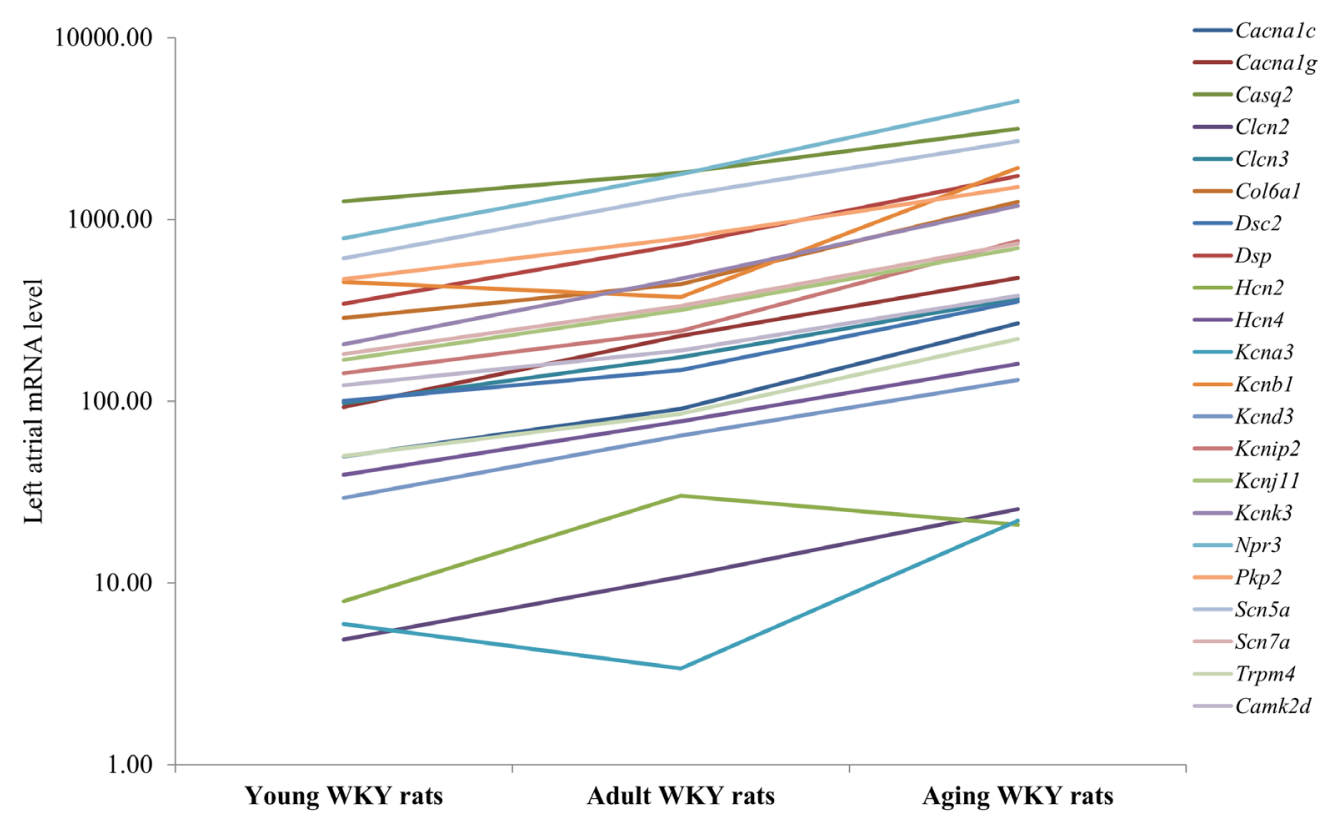

Figure 1. Left atrial mRNA expression for genes significantly differentially expressed between young, adult, and aging WKY rats $(\mathrm{n}=4$ each). Data are expressed as means. Results are shown in log scale.

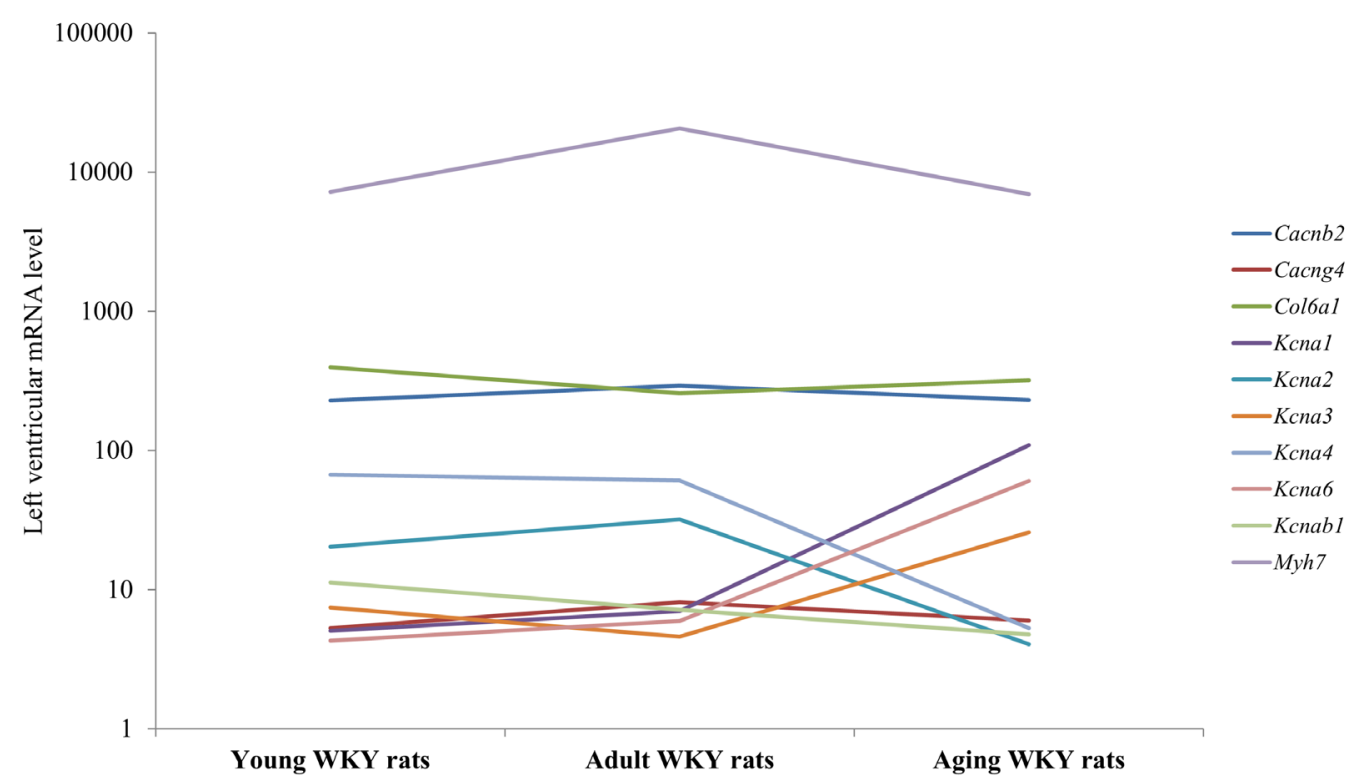

Figure 2. Left ventricular mRNA expression for genes significantly differentially expressed between young, adult, and aging WKY rats $(n=4$ each). Data are expressed as means. Results are shown in log scale. 
Transcripts with putative roles in aging-related cardiac arrhythmogenesis

At the atrial level, expression levels of several genes that have been previously related to increased arrhythmogenicity presented significant age-dependent changes.

Expression levels of Hcn4, encoding for $\mathrm{I}_{\mathrm{f}}$, were significantly higher in aging WKY rats compared to both young and adult WKY rats $(160.8 \pm 2.9$ in aging versus $77.4 \pm 0.3$ in adult versus $39.4 \pm 0.2$ in young WKY rats, $P=0.01$ ), and were significantly positively correlated with age (Spearman $r=0.93, P<0.001$ ). Similarly, expression levels of Cacnalc and Cacnalg, encoding for $\mathrm{I}_{\mathrm{Ca}-\mathrm{L}}$, and for the T-type $\mathrm{Ca}^{2+}$ current $\left(\mathrm{I}_{\mathrm{Ca}-\mathrm{T}}\right)$, respectively, were also significantly higher in aging WKY rats compared to both young and adult WKY rats $(268.6 \pm 6.5$ in aging versus $90.7 \pm 1.1$ in adult versus $49.8 \pm 0.7$ in young WKY rats, $P=0.01$, and $478.7 \pm 11.2$ in aging versus $228.9 \pm 0.3$ in adult versus $93.1 \pm 0.9$ in young WKY rats, $P=0.03$, respectively), and were significantly positively correlated with age (Spearman $r=0.88, P<0.01$, and Spearman $r=$ $0.86, P<0.01$, respectively).

Expression levels of four genes encoding for outward $\mathrm{K}^{+}$currents (Kcnd3, Kcnip2, Kcnj11, and $K c n k 3$ ) were also significantly higher in aging WKY rats compared to both young and adult WKY rats (Figure 3) and significantly positively correlated with age (Spearman $r=0.79, P=$ 0.02; Spearman $r=0.77, P=0.01$; Spearman $r=0.81, P=0.02$; and Spearman $r=0.96, P<$ 0.001 , respectively). Up-regulated expression of genes encoding for $\mathrm{I}_{\mathrm{Na}}(\operatorname{Scn} 5 a$ and $S c n 7 a)$ was also observed in aging WKY rats compared to both young and adult WKY rats (Figure 3) and were significantly positively correlated with age (Spearman $r=0.88, P<0.01$ for both genes).

Expression levels of Col6a1, encoding for type VI collagen, were also significantly higher in aging WKY rats compared to both young and

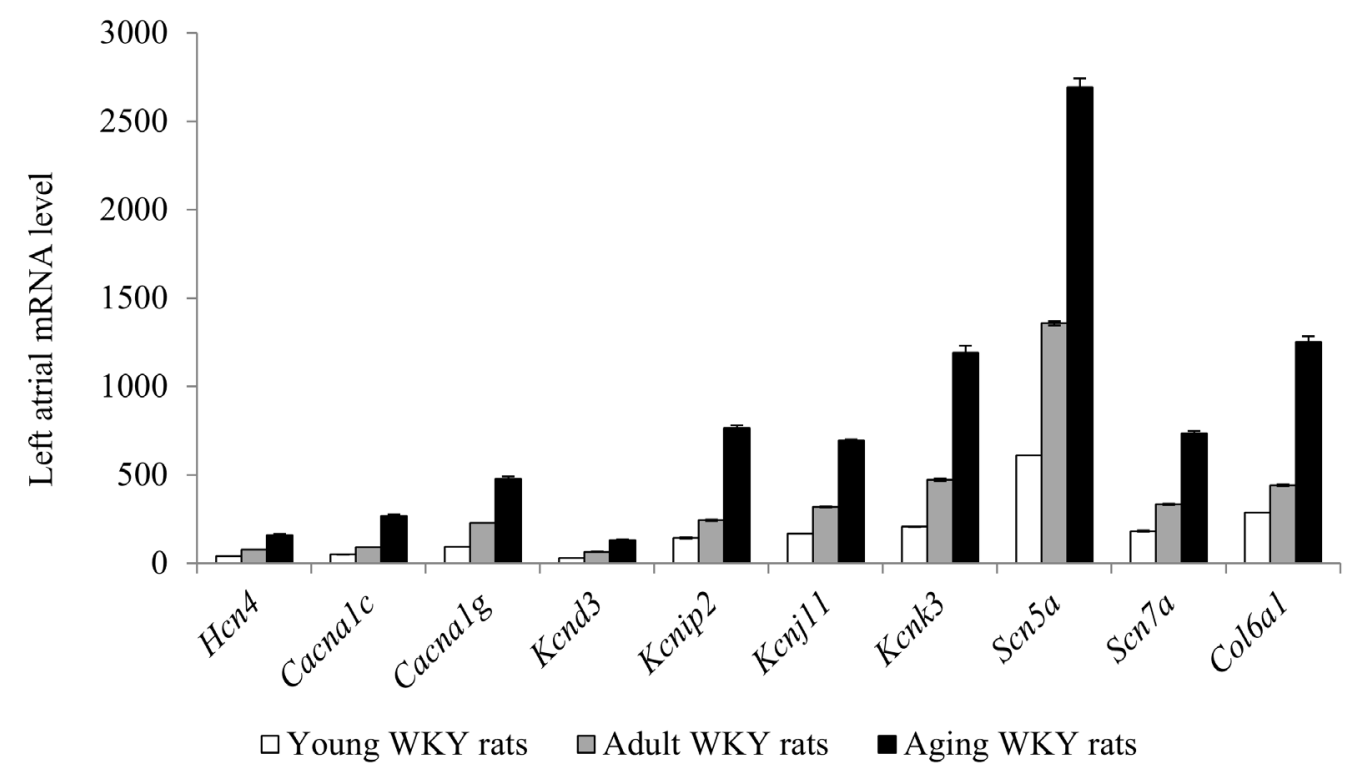

Figure 3. Age-dependency of left atrial mRNA expression levels for selected genes with putative roles in atrial arrhythmogenicity. Data are expressed as means $\pm \mathrm{SE}$. 
adult $(1251.2 \pm 34.0$ in aging versus $441.0 \pm 4.3$ in adult versus $286.9 \pm 0.4$ in young WKY rats, $P=0.01)$ WKY rats (Figure 3), and were significantly positively correlated with age (Spearman $r=0.94, P=0.001)$.

At the ventricular level, no transcriptional change could be related to a pro-arrhythmic pattern.

\section{Discussions}

The incidence of both atrial and ventricular arrhythmias increases progressively in the senescent heart $(1,2)$, even in the absence of apparent structural abnormalities (14). However, molecular bases underlying the increased propensity to arrhythmogenesis of the elderly remain incompletely understood. Transcriptome analyses seem well suited for providing deeper insights into the molecular pathophysiology of aging-related cardiac arrhythmogenesis and identifying potential targets for novel antiarrhythmic therapies.

\section{Steady expression profiles for the majority of studied genes}

Transcriptomic analysis of left atrial samples revealed a static expression profile for almost $45 \%$ of the studied genes with advancing age. With 64 genes out of the 89 studied genes (71.9\%) presenting similar ventricular expression levels in the three stages of the aging process, ventricular transcriptome displayed an even more stable profile. The large majority of genes presented stable mRNA levels in both the atria and the ventricles of rats of different ages. These genes, including genes encoding for calsequestrin 1, connexin-45, serine/threonine-specific protein kinase, or N-lysine methyltransferase, may indicate a panel of genes that are 'resistant' to both atrial and ventricular aging-related molecular remodeling.
Transcripts with putative roles in aging-related cardiac arrhythmogenesis

Our results indicate that the induction of an up-regulation transcriptional response is a common feature of atrial, but not ventricular, cellular aging. Moreover, none of the genes with significantly altered expression levels within the atrial tissue presented the same change within the ventricular tissue. These observations suggest that the two chambers of the heart undergo different molecular remodeling processes.

The most common arrhythmia found in the elderly is atrial fibrillation (AF), with a 100 -fold higher prevalence in octogenarians compared to those younger than 55 years of age (15-17). Two main electrophysiological mechanisms seem to underlie the occurrence of AF: focal ectopic activity and reentry circuits, favored by either altered electrical properties or by fixed structural changes of the atrial tissue. While ectopic activity can arise from increased cell automaticity outside the normal electrical system of the heart and/or the occurrence of afterdepolarizations, reentry has been related to decreased conduction velocity and/or atrial refractoriness shortening (18).

Increased automaticity originating in, but not confined to the pulmonary veins sleeve myocardium, plays an important role in AF genesis. Although the exact mechanisms that initiate abnormal automaticity are not well understood, it is well recognized that unusual presence of the pacemaker current $I_{f}$, which is responsible for the spontaneous diastolic depolarization in sinus node cells but normally lacks in cells outside the electrical system of the heart, as well as abnormal up-regulation of $\mathrm{I}_{\mathrm{Ca}-\mathrm{T}}$ in these cells, play a dominant role in this process (19). In the present study, one of the most obvious alterations in the aging atria was the up-regulation of Hcn4, encoding for the $\mathrm{I}_{\mathrm{f}}$ current. Moreover, aging atria also displayed up-regulated expression of $\mathrm{Cac}$ nalg, encoding for $\mathrm{I}_{\mathrm{Ca}-\mathrm{T}}$. Both these molecular 
abnormalities could underlie the higher propensity to atrial automaticity observed in the elderly.

Additionally, aging atria displayed up-regulated expressions of genes encoding for $\mathrm{I}_{\mathrm{Ca}-\mathrm{L}}$ and $\mathrm{I}_{\mathrm{Na}}$ currents, which could cause increased inward $\mathrm{Ca}^{2+}$ and/or $\mathrm{Na}^{+}$movement during action potential phases 2 or 3 , favoring the genesis of early afterdepolarizations. Fibrillating atria have been shown to exhibit significant $\mathrm{I}_{\mathrm{Ca}-\mathrm{L}}$ down-regulation, probably as an adaptive, protective mechanism designed to prevent the cytotoxic effects of intracellular $\mathrm{Ca}^{2+}$ overload (20). This mechanism appears to be involved in atrial refractoriness shortening and reentry. On the other hand, up-regulated expression of Cacnalc, encoding for $\mathrm{I}_{\mathrm{Ca}-\mathrm{L}}$, observed in our study, seems to characterize aging, but non-fibrillating atria, and may underpin intracellular $\mathrm{Ca}^{2+}$ overload, facilitating the formation of early afterdepolarization in aging atrial myocytes (21). Similarly, fibrillating atrial myocytes usually display a significant reduction in $\mathrm{I}_{\mathrm{Na}}$, which could contribute to decreased conduction velocity and reentry (22). However, aging non-fibrillating atrial myocytes seem to exhibit up-regulation of genes encoding for $\mathrm{I}_{\mathrm{Na}}$, which could further participate to the higher propensity to early afterdepolarizations of these cells. In fact, a gain of function mutation in the SCN5A gene encoding for $\mathrm{I}_{\mathrm{Na}}$ has been recently reported in a large Japanese family with AF (23), demonstrating the causative effect of $\mathrm{I}_{\mathrm{Na}}$ up-regulation in AF onset.

The significant up-regulation of several genes encoding for outward $\mathrm{K}^{+}$currents could favor atrial action potential and refractoriness shortening, predisposing aging atria to reentry. Atrial action potential and refractoriness shortening is often observed in patients with gain of function mutations in genes encoding for outward $\mathrm{K}^{+}$currents, including $\mathrm{KCND} 3, \mathrm{KCNJ} 11$, and KCNK3 (24-26). Furthermore, Col6al expression, encoding for non-fibrillar type 6 collagen, was significantly up-regulated in aging atria, in concordance with previous studies that demonstrate increased atrial fibrosis in this context (27). Up-regulated Col6al expression may be related to conduction slowing and thus further favor reentry.

At the ventricular level, no transcriptional change could be related to a pro-arrhythmic pattern. A number of genes presented significantly different ventricular expression levels in aging WKY rats compared to both adult and young WKY rats. However, ventricular transcriptomic profile seems to reflect the activation of a compensatory program in aging cells, with some genes encoding for a given ion channel being up-regulated while others are down-regulated, suggesting the activation of the repolarization reserve.

Our study demonstrates for the first time that a number of molecular features predisposing to atrial arrhythmias could be directly related to the aging process itself, explaining the higher propensity to atrial arrhythmias of the elderly. Contrarily, based on the panel of studied genes, it appears that the ventricular myocardium is much less 'sensitive' to molecular aging, explaining the lower propensity to ventricular than atrial arrhythmias of the elderly. However, despite the pro-arrhythmic atrial molecular profile, we previously demonstrated using continuous electrocardiographic recordings that aging WKY rats do not develop significant atrial arrhythmic events, contrary to aging spontaneously hypertensive rats, which displayed high atrial arrhythmogenicity (28). Taken together, these observations suggest that atrial molecular aging is not a sufficient condition but more likely a facilitator of atrial arrhythmogenicity, and that the presence of other factors, such as arterial hypertension, is needed in order to initiate the arrhythmias. A similar transcriptomic analysis in arrhythmic aging spontaneously hypertensive rats would therefore be of interest. 


\section{Potential therapeutic targets}

The use of antiarrhythmic agents in AF treatment and prevention of recurrences relies on the ability of these drugs to block $\mathrm{I}_{\mathrm{Na}}$ (class I antiarrhythmic agents), $\mathrm{I}_{\mathrm{Ca}-\mathrm{L}}$ (class IV antiarrhythmic agents), and outward $\mathrm{K}^{+}$currents (class III antiarrhythmic agents). However, among the genes that were most markedly up-regulated in our study was Hcn4, encoding for the $\mathrm{I}_{\mathrm{f}}$ current. Moreover, several other studies have demonstrated abnormal presence of $\mathrm{I}_{\mathrm{f}}$ in atrial myocytes, with altered expression of $\mathrm{HCN}$ isoforms in human AF. In the study of Lai et al. mRNA levels of $\mathrm{I}_{\mathrm{f}}$ were significantly correlated with left atrial filling pressure and AF (29), while Morel et al. demonstrated HCN4 expression in interstitial human pulmonary veins Cajal cells capable of generating electrical activity (30). Therefore, it seems reasonable to hypothesize that $I_{f}$ blockade might carry promising therapeutic potential, at least in some conditions that increase AF susceptibility. Several experimental studies have already demonstrated that $\mathrm{I}_{\mathrm{f}}$ blockade with Ivabradine is able to suppress spontaneous activities in isolated pulmonary veins $(31,32)$. Since $\mathrm{I}_{\mathrm{f}}$ is stimulated by beta-adrenergic activation of the adenylate cyclase-cAMP system, the combination of beta-blockers and specific $\mathrm{I}_{\mathrm{f}}$ current blockers is indeed expected to provide beneficial effects in patients with sympathetic AF. However, it seems unlikely for $I_{f}$ blockade to be efficient in other AF cases, such as vagally-mediated AF (33). The use of $I_{f}$ channel blockers in $\mathrm{AF}$ prevention and/or treatment is an emergent therapeutic strategy that deserves to be further studied.

\section{Limitations}

In this study, gene expression changes were only assessed by mRNA quantification. Although altered gene expression is expected to result in abnormal protein variations, other posttranscriptional or posttranslational regulato- ry mechanisms may influence protein level and function.

\section{Conclusions}

Our results indicate the induction of an up-regulation transcriptional response in atrial, but not ventricular myocytes with advancing age, suggesting that the two chambers of the heart undergo different molecular remodeling programs. Aging atria displayed a transcriptomic profile consistent with higher propensity to arrhythmias, including $\mathrm{I}_{\mathrm{f}}, \mathrm{I}_{\mathrm{Ca}-\mathrm{L}}, \mathrm{I}_{\mathrm{Ca}-\mathrm{T}}, \mathrm{I}_{\mathrm{Na}}$, outward $\mathrm{K}^{+}$currents, and collagen up-regulation, while ventricular transcriptome did not seem to be significantly altered by aging. Taken together, these observations could explain the higher propensity to atrial than ventricular arrhythmias in the elderly with no concomitant cardiac disorders.

\section{Disclosures: None}

\section{Acknowledgments and financial support}

The authors would like to thank Mrs. Valérie Oréa (Institut de Biologie et Chimie des Protéines, FRE 3310 CNRS/Université Claude Bernard Lyon1, Lyon, France), and Drs. Maximilien Giovannetti, Stéphane Wroblewski, and Daniel Grinberg for performing heart sampling. This research was partially supported by a University of Medicine and Pharmacy of Tîrgu Mureș Research Grant number 10/30.01.2013.
Abbreviations
$\mathrm{AF}=$ atrial fibrillation
cDNA = complementary DNA
$\mathrm{I}_{\mathrm{Ca}-\mathrm{L}}=$ L-type $\mathrm{Ca}^{2+}$ current
$\mathrm{I}_{\mathrm{Ca}-\mathrm{T}}=\mathrm{T}$-type $\mathrm{Ca}^{2+}$ current
$\mathrm{I}_{\mathrm{K}}=$ delayed rectifier $\mathrm{K}^{+}$current
$\mathrm{I}_{\mathrm{K} 1}=$ inward rectifier $\mathrm{K}^{+}$current
$\mathrm{I}_{\mathrm{K}-\mathrm{Ach}}=$ acetylcholine-activated $\mathrm{K}^{+}$current
$\mathrm{I}_{\mathrm{K} \text {-ATP }}=$ ATP-sensitive $\mathrm{K}^{+}$current 
$\mathrm{I}_{\mathrm{Na}}=$ voltage-dependent $\mathrm{Na}^{+}$current

$\mathrm{I}_{\text {to }}=$ transient outward $\mathrm{K}^{+}$current

TGF $\beta=$ transforming growth factor beta

TLDA $=$ TaqMan Low Density Array

WKY $=$ Wistar-Kyoto

\section{References}

1. Chow GV, Marine JE, Fleg JL. Epidemiology of arrhythmias and conduction disorders in older adults. Clin Geriatr Med. 2012 Nov;28(4):539-53. DOI: 10.1016/j. cger.2012.07.003

2. Mirza M, Strunets A, Shen WK, Jahangir A. Mechanisms of arrhythmias and conduction disorders in older adults. Clin Geriatr Med. 2012 Nov;28(4):555-73. DOI: 10.1016/j.cger.2012.08.005

3. Brembilla-Perrot B. Age-related changes in arrhythmias and electrophysiologic properties. Card Electrophysiol Rev. 2003 Jan;7(1):88-91. DOI: 10.1023/A:1023611727947

4. Sohal RS, Weindruch R. Oxidative stress, caloric restriction, and aging. Science. 1996 Jul;273:59-63. DOI: 10.1126/science.273.5271.59

5. Ramsey JJ, Harper ME, Weindruch R. Restriction of energy intake, energy expenditure, and aging. Free Radic Biol Med. 2000 Nov;29:946-68. DOI: 10.1016/ S0891-5849(00)00417-2

6. Golden TR, Hinerfeld DA, Melov S. Oxidative stress and aging: beyond correlation. Aging Cell. 2002 Dec;1:11723. DOI: 10.1046/j.1474-9728.2002.00015.x

7. Gavrilov LA, Gavrilova NS. Evolutionary theories of aging and longevity. Sci World J. 2002 Feb;2:339-56. DOI: $10.1100 /$ tsw.2002.96

8. Volkova M, Garg R, Dick S, Boheler KR. Aging-associated changes in cardiac gene expression. Cardiovasc Res. 2005 May;66(2):194-204. DOI: 10.1016/j.cardiores.2004.11.016

9. Gaborit N, Wichter T, Varro A, Szuts V, Lamirault G, Eckardt L, et al. Transcriptional profiling of ion channel genes in Brugada syndrome and other right ventricular arrhythmogenic diseases. Eur Heart J. 2009 Feb;30(4):487-96. DOI: 10.1093/eurheartj/ehn520

10. Boheler KR, Volkova M, Morrell C, Garg R, Zhu Y, Margulies K, et al. Sex- and age-dependent human transcriptome variability: Implications for chronic heart failure. Proc Natl Acad Sci U S A. 2003 Mar; 100(5):2754-9. DOI: $10.1073 /$ pnas.0436564100

11. Melov S, Coskun PE, Wallace DC. Mouse models of mitochondrial disease, oxidative stress, and senescence. Mutat Res. 1999 Jul;434: 233-42. DOI: 10.1016/ S0921-8777(99)00031-2

12. Liang H, Masoro EJ, Nelson JF, Strong R, McMahan CA, Richardson A. Genetic mouse models of extended lifespan. Exp Gerontol. 2003 Nov-Dec;38:1353-64.
DOI: 10.1016/j.exger.2003.10.019

13. Jazwinski SM. Aging and longevity genes. Acta Biochim Pol. 2000;47:269-79.

14. Fuster V, Ryden LE, Cannom DS, Crijns HJ, Curtis $\mathrm{AB}$, Ellenbogen KA, et al. $2011 \mathrm{ACCF} / \mathrm{AHA} / \mathrm{HRS}$ focused updates incorporated into the $\mathrm{ACC} / \mathrm{AHA} /$ ESC 2006 guidelines for the management of patients with atrial fibrillation: A report of the American College of Cardiology Foundation/American Heart Association task force on practice guidelines. Circulation. 2011 Mar;123:e269-36713. DOI: 10.1161/ CIR.0b013e318214876d

15. Roger VL, Go AS, Lloyd-Jones DM, Benjamin EJ,Berry JD,Borden WB, et al. Executive summary: heart disease and stroke statistics-2012 update: a report from the American Heart Association. Circulation. 2012 Jan;125(1):188-97. DOI: 10.1161/ CIR.0b013e3182456d46

16. Miyasaka Y, Barnes ME, Gersh BJ, Cha SS, Bailey KR, Abhayaratna WP, et al. Secular trends in incidence of atrial fibrillation in Olmsted County, Minnesota, 1980 to 2000, and implications on the projections for future prevalence. Circulation. 2006 Jul;114:119-25. DOI: 10.1161/CIRCULATIONAHA.105.595140

17. Mozaffarian D, Furberg CD, Psaty BM, Siscovick D. Physical activity and incidence of atrial fibrillation in older adults: the cardiovascular health study. Circulation. 2008 Aug;118:800-7. DOI: 10.1161/CIRCULATIONAHA. 108.785626

18. Wakili R, Voigt N, Kääb S, Dobrev D, Nattel S. Recent advances in the molecular pathophysiology of atrial fibrillation. J Clin Invest. 2011 Aug;121(8):2955-68. DOI: $10.1172 / J C I 46315$

19. Nattel S, Li D, Yue L. Basic mechanisms of atrial fibrillation: very new insights into very old ideas. Annu Rev Physiol. 2000;62:51-77. DOI: 10.1146/annurev.physiol.62.1.51

20. Yamada M, Ohta K, Niwa A, Tsujino N, Nakada T, Hirose $\mathrm{M}$. Contribution of L-type $\mathrm{Ca} 2+$ channels to early afterdepolarizations induced by $\mathrm{I} \mathrm{Kr}$ and I Ks channel suppression in guinea pig ventricular myocytes. J Membr Biol. 2008 Apr;222(3):151-66. DOI: 10.1007/ s00232-008-9113-9

21. Van Wagoner DR, Pond AL, Lamorgese M, Rossie SS, McCarthy PM, Nerbonne JM. Atrial L-Type Ca2+ currents and human atrial fibrillation. Circ Res. 1999 Sep;85:428-36. DOI: 10.1161/01.RES.85.5.428

22. Gaspo R, Bosch RF, Bou-Abboud E, Nattel S. Tachycardia-induced changes in $\mathrm{Na}+$ current in a chronic dog model of atrial fibrillation. Circ Res. 1997 Dec;81:104552. DOI: 10.1161/01.RES.81.6.1045

23. Makiyama T, Akao M, Shizuta S, Doi T, Nishiyama K, Oka Y, et al. A novel SCN5A gain-of-function mutation M1875T associated with familial atrial fibrillation. J Am Coll Cardiol. 2008 Oct;52(16):1326-34. DOI: 
10.1016/j.jacc.2008.07.013

24. Olesen MS, Refsgaard L, Holst AG, Larsen AP, Grubb $\mathrm{S}$, Haunsø S, et al. A novel KCND3 gain-of-function mutation associated with early-onset of persistent lone atrial fibrillation. Cardiovasc Res. 2013 Jun;98(3):48895. DOI: $10.1093 /$ cvr/cvt028

25. Olson TM, Alekseev AE, Moreau C, Liu XK, Zingman LV, Miki T, et al. KATP channel mutation confers risk for vein of Marshall adrenergic atrial fibrillation. Nat Clin Pract Cardiovasc Med. 2007 Feb;4(2):110-6. DOI: 10.1038/ncpcardio0792

26. Limberg SH, Netter MF, Rolfes C, Rinné S, Schlichthörl G, Zuzarte M, et al. TASK-1 channels may modulate action potential duration of human atrial cardiomyocytes. Cell Physiol Biochem. 2011;28(4):613-24. DOI: 10.1159/000335757

27. Frustaci A, Chimenti C, Bellocci F, Morgante E, Russo MA, Maseri A. Histological substrate of atrial biopsies in patients with lone atrial fibrillation. Circulation. 1997 Aug;96(4):1180-4. DOI: 10.1161/01.CIR.96.4.1180

28. Scridon A, Gallet C, Arisha MM, Oréa V, Chapuis B, Li N, et al. Unprovoked atrial tachyarrhythmias in aging spontaneously hypertensive rats: The role of the autonomic nervous system. Am J Physiol Heart Circ Physiol. 2012 Aug;303(3):H386-92. DOI: 10.1152/ ajpheart.00004.2012
29. Lai LP, Su MJ, Lin JL, Tsai CH, Lin FY, Chen YS, et al. Measurement of funny current (I(f)) channel mRNA in human atrial tissue: Correlation with left atrial filling pressure and atrial fibrillation. J Cardiovasc Electrophysiol. 1999 Jul;10:947-53. DOI: 10.1111/j.15408167.1999.tb01265.x

30. Morel E,Meyronet D, Thivolet-Bejuy F, Chevalier P. Identification and distribution of interstitial Cajal cells in human pulmonary veins. Heart Rhythm. 2008 Jul;5:1063-7. DOI: 10.1016/j.hrthm.2008.03.057

31. Suenari K, Cheng CC, Chen YC, Lin YK, Nakano Y, Kihara Y, et al. Effects of Ivabradine on the pulmonary vein electrical activity and modulation of pacemaker currents and calcium homeostasis. J Cardiovasc Electrophysiol. 2012 Feb;23(2):200-6. DOI: 10.1111/j.1540-8167.2011.02173.X

32. Li Y, Huang Y, Li Z, Wang H, Song J, Liu Y, et al. Effect of ivabradine on hyperpolarization activated cation current in canine pulmonary vein sleeve cardiomyocytes with atrial fibrillation J Geriatr Cardiol. 2008;5(1):3942.

33. Xue X, Yan GX. The funny current (If): is it a novel antiarrhythmic target to treat atrial fibrillation? J Cardiovasc Electrophysiol. 2012 Feb;23(2):207-8. DOI: 10.1111/j.1540-8167.2011.02209.x 